\title{
Facts, Theories, and Policies in the History of Economics. An Introductory Note
}

\author{
Fabio Masini*
}

\section{Introduction}

Alan Blinder, economist at Princeton with a long record of policy advice, opened a successful book explaining "Murphy's Law of Economic Policy: Economists have the least influence on policy where they know the most and are most agreed; they have the most influence on policy where they know the least and disagree most vehemently" (Blinder 1987: 1). This seems to be a pessimistic claim. But it still implies that there is an area of consensus in which economists can dwell, although irrelevant to policymaking ${ }^{1}$.

Our feeling is much more pessimistic: that neither of the two propositions in Murphy's Law of Economic Policy is probably true. Hardly any consensus exists among economists on most parts of economic theory: the area over which they are ignored by policy makers is much larger than the area of their agreement. At the same time, the Law suggests that policymakers appreciate the critical debates among economists and are able (and willing) to use such debates to assist their public choices. We are inclined to be skeptical also about this conclusion.

In order to inquire on this and on the long debated relationship between economic theories and policies (for instance Coats 1981, 1986; Barber 1985; Pechman 1989; Augello and Guidi 2005; Bini and Tusset 2008), a group of historians of economics joined a common project on the study of specific national cases since WWII. In September 2011 we gathered in Rome to discuss the results of these enquiries and this issue of the journal is the collection of most of these works ${ }^{2}$.

\footnotetext{
* Department of Political Science, University of Roma Tre; E-mail: fabio.masini@uniroma3.it. Given the usual disclaimer, I would like to thank Pier Francesco Asso, Roger Backhouse, Bradley Bateman and Piero Bini for their help in discussing and revising the text.

${ }^{1}$ It further implies that the problem might be only a matter of communication failure, as Rees (1986: 138) suggests: "economists do a very bad job of communicating the principles on which [they] agree”.

${ }^{2}$ At the workshop, other papers were presented. Among them, Francesco Cattabrini's paper on
} 
What follows is an attempt to introduce this research project addressing a more general question (in which another protagonist comes in): the relationship among facts, theories and policies.

\section{Exogenous vs interdependent interpretative models}

Theories, events and public choices are closely interdependent factors in the processes of production and circulation of ideas. Nevertheless, a division of labour has tended to emerge (Cairncross 1996: 3) in the academic studies, where each of the three factors has become the core object of study by specialized intellectuals, who sometimes overlook the complex relations among these factors. Some have even theorized the lack of any such interdependence: for example, endogenous theories of progress in economic analysis assume that economic theory evolves only for internal reasons defined by theorists in the discipline (Rostow 1957: 510 and 1986: 70ff; Stigler 1960: 40).

If we think of these three factors as the vertices of a triangle ${ }^{3}$, we can observe that, very often, the literature ventures to single out causal nexuses along the perimeter of that triangle, between couples of vertices ${ }^{4}$. Let us provide some examples of interpretative lines of thought that have followed this approach.

\subsection{Events and theories}

The importance of facts to theory has been stressed for several reasons. As Arrow (1986: 15) suggests, facts provide a test for theories: although some theories can be strong enough that economic theorists can neglect factual evidence that runs counter to them, generally speaking, a continuous gap between factual evidence and economic theory provides incentives for and can lead to the emergence of new paradigms. Events - although for Stigler (1960: 38) and Spengler (1960: 52) only major and global ones - may even suggest solutions for theoretical problems (Cairncross 1996: 6). Furthermore, historical events are the ground where theories are born and live (Machlup 1960: 52). Accordingly, theories are only valid and explainable within specified historical contexts (Solow 1986: 23 24; Temin 1986: 58; Wright 1986: 79 ff) and for McCloskey (1986: 64) economic theory and history cannot - and should not - be regarded as two separate bodies but as a unique discipline.

the "Modigliani controversy" was published in the 2012-1 issue of this journal, and Ivo Maes's paper on Padoa-Schioppa is forthcoming in the next 2013-2 issue.

${ }^{3}$ An interesting debate took place (in English) in the journal Storia del Pensiero Economico (issue 2005-2) on a (different) triangular representation of the history of economics based on a contribution by Piero Barucci (2005) and comments by Roger Backhouse, Piero Bini, Antonio Gay, Nicola Giocoli, Bruno Jossa, Daniela Parisi, Pier Luigi Porta, and Paolo Savona. Although many arguments of that debate differ substantially from the ones expressed here, some similarities exist that should be better explored.

${ }^{4}$ An interesting similar argument was expressed by Fontaine and Marciano (2007: 568). 


\subsection{Events and policies}

Also as concerns the relationship between facts and policies, perimetral relations are outlined: for instance, it is often claimed that policies are the response to specific events; but also the feedbacks of policies on facts is underlined. Cairncross (1996), for example, argues that policies, changing expectations, impact the timing and emergence of particular historical events, even some of major importance. Policies may also influence directly historical events, with specific normative changes that can cause adverse reactions or adjustment processes.

\subsection{Theories and policies}

Finally, the relationship between theories and policies has been studied mainly from three - again linear - perspectives, which have variously contributed to the understanding of specific cases in history (for example Hutchison 1969; Booth and Coase 1980; Backhouse 2004). First, policy-makers demand economic theories in support for their choices (Hall 1989). This is the approach we might name instrumental because, as Homan (1960: 48) observes, "theory is instrumental to policy". Shackle (1966: 29) distinguishes between economists who are within and those who are outside the battle of public choices. Both of them can play a fundamental role in forging policies. Economists who are in the battle (in Government, in Parliament, or in some other relevant public body) may be more constrained than outsiders (advisors) and find it more difficult to express and apply their theoretical views; but this may even be just a signal of greater responsibility towards a common, superior interest (Booth 1986: 674).

Secondly, claiming that theories and policies have an autonomous status and evolution (Krueger 1999: 33), many authoritative authors argue against any possible influence of economists on public choices (Samuelson 1962: 17; Stigler 1965: 12), even when they themselves have directly worked as influential advisors of policymakers, as they both have. Others recognize, but minimize, such influences (Calkins 1966: 530; Cornelius 1990: 427). Booth and Coats (1980) suggest that economists might feel less comfortable in the arena of economic policy than in the academia, therefore keeping detached from public policymaking.

Thirdly, those who agree with Keynes's notorious quotation from The General Theory that "practical men, who believe themselves to be quite exempt from any intellectual influences, are usually slaves of some defunct economist", believe that economists are the true inspiration for economic policies, or that they at least provide some fundamental analytical skills (Hamilton 1992; Abraham 2005), whose success may even increase the confidence of policymakers towards economists (Jacoby 1971: 410) and "facilitate intelligent choice" (Homan 1960: 48).

Other less common perspectives are those of Coats (1999: 85) claiming that "policy advice" is "vital for the profession" because the experience of engaging with policy makers helps economists forget the "brainwashing" in their training, obliging them to face practical problems which might require solutions that differ from elegant theoretical modeling (Galbraith 1973). 


\subsection{Exogenous vs interdependent models}

A common feature of these approaches, focused on the edges of the triangle, is that they consider one-way or reciprocal influences between pairs of poles. They use what may be called exogenous interpretative models, in that they study the reaction of an element to an exogenous change in another one (how theories respond to facts, and vice-versa; how theories influence policies, etc.).

Nevertheless, the interpretative capacity of such models can be weak, sometimes misleading. The network of relationships that evolve within the whole area of the triangle itself remains hidden. Indeed, the relationship among theories, public choices, and events is usually much more complex, less linear, often twodirectional, with some unforeseeable short circuits. In order to tackle such complexity, it is necessary to use a model which assumes a high degree of interdependence between such variables and focuses on the evolution of their mutual interactions over time. The peculiar role of the history of economic thought is precisely to reconstruct the complex and interdependent relationships - evolving in historical time - among facts, theories and policies. As a discipline, we work to fill the entire triangle, not just to understand its perimeter.

\section{Complexity, nirvana fallacy, and some key questions}

Leaving the perimeter and trespassing inside the triangle is a step towards dangerous and difficult epistemological questions: within that area the infinite coordinates of proximity to the three vertices give rise to an enormous variety of approaches to the way of doing the history of economic thought. Depending on the specific interest and sensitivity of each scholar, his analysis may be pulled by one or more of the three vertices. Some feel more concerned with the history of economic analysis, others with intellectual history, etc.; hence the pluralistic attitude and nature of the history of economic thought.

One of its crucial roles is to identify and analyze the intricate interactions between theory, facts and policy and putting them in a specific context characterized by time, space and institutional coordinates. This is what the contributors to this project have been trying to do taking as their subject matter national case studies from the period since the end of the Second World War.

We are indeed aware of a sort of nirvana fallacy problem when writing such history. It is impossible to reconstruct the complex set of relations among the three aspects, especially if, as this is the case, the time span considered is considerable. Interpretative simplifications are therefore necessary.

What we have done with this tentative research project is to try to focus on some key questions to be addressed concerning such relationships. Are the relevant facts, theories and policies the same in each national case? Is there any specific national character at all which can be identified in the circulation of economic information and knowledge? Are interests more powerful than ideas? Are interests in need of ideas at all? Are the channels through which economists 
have influenced policymaking the same everywhere? What was the role of intermediate institutions such as think-tanks, the financial press, etc. in connecting theory to policy?

We are not suggesting that any definitive answer is attainable from this research effort. Only more comprehensive, perhaps even interdisciplinary, work carried out systematically in each country would have any hope of achieving that. Our goal when we started this research was only to explore these topics, hoping we might succeed in convincing others that further inquiry in this direction is worth pursuing. Before turning to the case studies, I offer a few further reflections to illustrate what I think should be regarded as key features emerging from the following papers.

\subsection{National specificity}

Irrespective of the rhetoric of globalization, nationality should still be considered a relevant factor in the way economic ideas circulate. No doubt, it can be argued that some major events like the end of WWII, the collapse of the dollar exchange standard, the oil shocks, the fall of the Berlin wall, or the advent of the single currency in Europe, have all dramatically affected the countries here considered. However, country-specific factors determine national differences.

Similarly, as concerns theories, Keynesianism, monetarism, and the new classical macroeconomics involved major paradigm shifts that played some role in every country considered. However, the extent and timing of their success differed significantly across the countries. In short, despite the transnational, or global, dimension of some events and theories, a national perspective is often necessary to study the way these three factors interact. The question is why.

Of course, country-specificity may be attributed to the third pole of the triangle, i.e. to the fact that public policies depend on national authorities, that the (national) constituency is the one which is most relevant in public choices, that policymaking impacts the people and territory and this requires that we consider the nation state and the way it has shaped the outcomes.

This is certainly true, but we feel that the reason is more profound: if the shape and specificity of the triangle formed by facts, theories and policies depends on the working of institutions which enable a dialogue among these three poles, it is plausible that specific national models exist in the way they interact among them.

Such specificity, in short, is not just a matter of national politics (government), but depends on the existence of intermediate (between economic theorizing and policy-making) institutions, such as trade unions, mass media (Parsons 1989), think tanks (Smith 1989; Cockett 1994; Backhouse 2005), as well as local and regional administrations (Wyplosz 1999: 64), organizations from civil society, etc. which have evolved in the last centuries along the building up of nation-states. And it depends on the peculiar way their intertwined relationships evolved over time.

Although it can be strongly questioned, we claim that also Central Banks should be regarded among those intermediate institutions. They do represent of course part of the economic policy-making, but they are normally not accounta- 
ble towards national constituencies, and sometimes not even to governments, therefore acting as independent (but inter-twined) institutions.

In any case, the point we want to raise is that, parallel to a framework of global threads which are common to the whole of humankind (or a major part of it), national specific stories are significant. And they are because the way in which major events and theories influence debates and policy-making differs according to the economic, social, political and even academic, cultural, civil institutions characterizing each country. The following papers provide interesting examples.

According to Johan Lönnroth, the role of think tanks in Sweden has been largely overestimated, but he agrees that the Central Bank played a key role both in constraining policymakers and in working out a peculiar theoretical apparatus for the role and functioning of monetary policy.

In Italy, both think-tanks and trade-unions - but also the central bank and the employers' federation - were fundamental to changing the patterns of policymaking between the Sixties and the Eighties. In particular, Italian trade unions, thanks also to many economists grouped in the research centre of the Communist Party, accepted the arguments concerning a decreasing interpretative capacity of a trade-off along the Phillips Curve to adopt a more "responsible" incomes policy and help the Left acquire credibility as a governmental force.

Also in Great Britain, the Institute for Economic Affairs played an important role in the policy turn brought about by Margaret Thatcher; and in Germany, the Council of Economic Advisors played a crucial role in the evolution of the relative strength of economic theories in policymaking after its foundation in 1963.

Our feeling, in short, is that the existing literature on the transfer of economic knowledge is sometimes flawed by oversimplification and neglect of relevant actors and that a more accurate study of the role of intermediate actors in each national country would cast greater light on the way the complex relations among facts, theories and policies interact.

\subsection{Challenging commonplaces}

Another point related to the question of country-specificity is that this is also a relevant factor to illustrate an important role of the history of economic thought. Commonplaces tend to emerge about the way events and/or theories influence economic policies. Most history of economic thought challenges such commonplaces and provides a more accurate explanation of the extent and means through which facts, theories and policies impact on one another.

It is often claimed, for example, that in the Seventies the end of Bretton Woods and the two major oil shocks supported the ascent of the new classical macroeconomics, which first won academic battles and then entered policymaking at the end of the decade. But the essays presented here tell us different (country-specific) stories.

In Spain, for example, the death of the dictator Franco was a more powerful event for institutional and theoretical change than the end of fixed exchange rates and the advent of monetarism. In Japan, the first oil shock brought about a 
contractionary policy, but that was done in order to stop the "great inflation" which had mounted before the shock. The Bank of Japan could change direction only after the shock because the sudden and dramatic rise in oil prices made a strict monetary stance become more politically sustainable. In the United States, the difference between the way monetarism was conceived in the academia and the way it was thought of and used at the Federal Reserve was profoundly different. The renowned monetarist shift at the end of the Seventies appears to be inconsistent with the real timing of the adoption of monetary targeting by the Fed. In Italy, there was no shift at all towards stricter monetary and fiscal policies. And actually, the celebrated divorce between the Bank of Italy and the Treasury in 1981 was far from representing a success for monetarist thinking, as it actually took the onus off policy-makers as concerns the growth of public debt.

Harald Hagemann reminds us of the story of the German Sonderweg, an interpretative model underlying the specificity of institutional change in Germany compared to the rest of Europe. But, reading the following essays, we have the feeling that each country has its own Sonderweg to be told and explained.

\subsection{Interests, ideas and ideologies}

The last point I would like to raise concerns the specific side of the triangle connecting economic theories and policies.

Two radically different approaches characterize the idea we have of politicians. On the one side, they are considered as the supreme expression of a collective choice, aiming at maximizing the welfare of the constituency, which the institution they manage represents (think of Harold Laski and some narrative on welfare economics in the Pigouvian tradition ${ }^{5}$ ). On the other side, politicians are merely supposed to make decisions to strengthen their political power (Ronald Coase, Harold Demsetz, James Buchanan, etc).

In both cases, they may require theoretical support. But the nature of that support is clearly different. In the former case, economists are supposed to help governments pursue the general interest; they might be tempted to influence the final decisions with their ideological or theoretical bias but it is a sort of unintended outcome. Ideas seem to be more powerful than interests.

In the second case, economists are perfectly aware of the relative forces in operation and mainly try to satisfy as best as they can the demands from their employers; their theoretical apparatus is simply "lost in the battle of interest groups" (Kirchgässner 1999: 16). In such cases, "the only purpose of enrolling economists as policy advisers is to serve the political positions of various interest groups" (Ibid.): interests are more powerful than ideas ${ }^{6}$.

\footnotetext{
${ }^{5}$ Although Pigou himself was very skeptical about the virtues of the governing elites, as Backhouse and Medema (2012) have recently pointed out.

${ }^{6}$ Think of the arguments by Janine Wedel (2001) on the use of western economists in the soviet transition to capitalism or Gunnar Myrdal's (1954: 191) claim that only when "interest harmony prevails, economists can make universally valid recommendations”.
} 
Our feeling is that the relative strength of interests and ideas may depend not only on the objective specificity of particular situations (Tomlinson 1984: 262; Coats and Colander 1989: $12 \mathrm{ff}$ ) but also on the subjective perspective from which the observer looks at politicians. There is no doubt, for example, that the advent of the Public Choice School changed not only the perception we have of politicians but also the general ideas on the role economists play in the backstage of the political struggle.

Another point worth mentioning is that, interests and ideas are not the only relevant protagonists in their reciprocal relationship. Ideologies may play a crucial role in connecting interests and ideas. I am not willing to dwell on slippery fields of long-lasting debates about the relationship between economic theories and ideologies (Heilbroner 1953, 1993; Solow 1971; Backhouse 2010). But some of the papers that follow testify to a great influence of ideologies in the way economic theorizing has influenced policy-making.

For example, the Sraffian theoretical apparatus in Italy between the end of the 1960s and the 1970s has served a widespread quest for a radical institutional, political and economic change. Piero Bini suggests that it has assisted an ideology of political change almost irrespective of its inherent soundness or of the sympathy for the specific analytical framework it implied: Sraffa's economic critique of marginalism was meant mainly as an instrument to attempt a revolt against the dominating political order. The fact that it permeated academic and policy debates is not evidence against this because, when the interest of the political and trade-unionist Left changed in the middle of the 1970s, thanks to the opportunity to become a governmental force, many economists were ready to change their theoretical reference and the Sraffian theories were increasingly marginalized. In that case, ideologies made theories so powerful as to challenge specific economic policies and politics first, and later so weak as to be quickly dismissed when they became politically dangerous.

And it is not just a matter of timing. Of course ideologies were very strong in the Seventies. But are we really sure that ideologies did not play an analogous or even more important - role in the last three decades? I suspect they did.

Think of the role of neoliberal ideologies in the management of the international institutions and their conditionality for financial support; or the widespread call for Keynesian theories after the last financial bubble, just to support economic policy demands in favour of expansionary budgetary policies designed only to meet political needs, without any reference to the real knowledge of Keynes's theoretical apparatus and policy prescriptions.

Interests, in short, still very often require (and are inclined to fuel) strong ideologies in order to demand theories that may support decisions of sectional economic policies. 


\section{Concluding remarks}

One of the most problematic questions arising from the study of the interrelations among facts, theories and policies is that the way these three elements interact depends on several features, which in turn depend on the time and space coordinates of observations, and on the role of a set of intermediate institutions which ease or hinder the speed of impulses and feedbacks transferred among them.

Irrespective of the relevance of major events and theories, most of the features that characterize such interactions are country specific. As Cornelius (1990) observed, the relationship between economic advisors and policy-making is strongly dependent on the institutions of each national constitutional system. This study confirms this.

As concerns the relative power of interests and ideas, we all know Keynes's (1936: 383) claim that "the power of vested interests is vastly exaggerated compared with the gradual encroachment of ideas [...] soon or late it is ideas, not vested interests, which are dangerous for good or evil"' . Following what emerges from the national inquires, we tend to agree with Henderson (1986), Hall (1989) and Winch (1969: 24) and consider this to be "wishful thinking".

It would certainly be too simplistic to argue that "it is politicians, not expert economists [who] direct national economic policy” (Helppie 1990: 207). Economists do play an important role, but mainly serving ideological or sectional interests. The studies here presented found evidence supporting Kirchgässner's (1999: 23) claim that: "we can find economists providing scientific support for nearly every political position. Apart from other factors, this is possible because economic theory is compatible with nearly all (factual) statements".

The triangle between facts, theories and policies, within which the history of economic thought is called to study the evolving coordinates of proximity, is itself a changing figure, which widens, shrinks, stretches along one or more sides depending, among other things, on both ideological pressures and on the way intermediate institutions interact within the triangle itself.

Despite a globalized and interdependent world and the narrative concerning the "end of history", the following papers show that country specificity and ideological bias are still the two most relevant features in some fields of research in the history of economic thought.

\footnotetext{
${ }^{7}$ A notorious case study along this line of thought is Seldon (1981), who illustrates the evidence concerning the Institute of Economic Affairs; the book was published by the IEA itself.
} 


\section{References}

Abraham K.G. (2005). Distinguished Lecture on Economics in Government: What We don't Know Could Hurt Us: Some Reflections on the Measurement of Economic Activity, The Journal of Economic Perspectives, 19(3): 3-18.

Arrow K. (1986). History: the View from Economics. In Parker (ed.)(1986): 13-20.

Augello M.M. and M.E.L. Guidi (2005). The Italian Economists in Parliament from 1860 to 1922: a Quantitative Analysis, The European Journal of the History of Economic Thought, 12(2): 279-319.

Backhouse R.E. (2004). History of Economics, Economics and Economic History in Britain, 1824-2000, The European Journal of the History of Economic Thought, 11(1): 107-127.

Backhouse R.E. (2005). The Rise of Free Market Economics: Economists and the Role of the State since 1970, History of Political Economy, 37(s1): 355-392.

Backhouse R.E. (2010). The Puzzle of Modern Economics. Science or Ideology?, Cambridge, Cambridge University Press.

Backhouse R.E. and S.G. Medema (2012). Economists and the Analysis of Government Failure: Fallacies in the Chicago and Virginia Interpretations of Cambridge Welfare economics, Cambridge Journal of Economics, 36(4): 981-994.

Barber W.J. (1985). From New Era to New Deal. Herbert Hoover, the Economists, and American Economic Policy, 1921-1933, Cambridge, Cambridge University Press.

Barucci P. (2005). On the Circular Process of Evolution of Economic Theory, Storia del Pensiero Economico, 2: 81-96.

Bini P. and G. Tusset (eds.)(2008). Theory and Practice of Economic Policy. Tradition and Change, Milano, FrancoAngeli.

Blinder A. (1987). Hard Heads, Soft Hearts: Tough-Minded Economics for a Just Society, Reading (Mass.), Addison-Wesley.

Booth A. (1986). Economic Advice at the Centre of British Government, 1939-1941, The Historical Journal, 29(3): 655-675.

Booth A. and A.W. Coats (1980). Some Wartime Observations on the Role of the Economist in Government, Oxford Economic Papers, 32(2): 177-199.

Cairncross A. (1996). Economic Ideas and Government Policy. Contributions to Contemporary Economic History, London, Routledge.

Calkins R.D. (1966). The Production and Use of Economic Knowledge, The American Economic Review, 56(1/2): 530-537.

Coats A.W. (ed.)(1981). Economists in Government: An International Comparative Study, Durham (N.C.), Duke University Press.

Coats A.W. (ed.)(1986). Economists in International Agencies. An Exploratory Study, New York: Praeger.

Coats A.W. (1999). Economic Policy Advice: Opportunities and Limitations. In Mohr (ed.)(1999): 74-89.

Coats A.W. and D.C. Colander (1989). An Introduction to The Spread of Economic Ideas. In Colander and Coats (eds.)(1989): 1-22.

Cockett R. (1994). Thinking the Unthinkable. The Think-Tanks and the Economic Counter-Revolution, 1931-1983, London, Fontana Press.

Colander D.C. and A.W. Coats (eds.)(1989). The Spread of Economic Ideas, Cambridge, Cambridge University Press.

Cornelius P.K. (1990). Economic Advice from the Inside or the Outside, European Journal of Political Economy, 6: 415-428.

Fontaine P. and A. Marciano (2007). The Political Element in Economic Thought, History of Political Economy, 39(4): 567-570. 
Galbraith J.K. (1973). Power and the Useful Economist, The American Economic Review, 63(1): $1-11$.

Hall P. (1989). The Political Power of Economic Ideas: Keynesianism Across Nations, New Jersey, Princeton University Press.

Hamilton L.H. (1992). Economists as Public Policy Advisers, The Journal of Economic Perspectives, 6(3): 61-64.

Hausman D.M. (ed.)(1994). The Philosophy of Economics: An Anthology, Cambridge, Cambridge University Press, 2nd ed.

Heilbroner R. (1953). The Worldly Philosophers. The Lives, Times, and Ideas of the Great Economic Thinkers, New York, Simon \& Schuster.

Heilbroner R. (1993). Was Schumpeter Right after all?, Journal of Economic Perspectives, 7(3): 87-96.

Helppie C.E. (1990). Mergers: Significance for Structure, Performance and Public Policy Session Comment, Review of Industrial Organization, 5(2): 207-209.

Henderson D. (1986). Innocence and Design: The Influence of Economic Ideas on Policy, Oxford, Basil Blackwell.

Homan P.T. (1960). Economic Theory and Economic Policy - Discussion, The American Economic Review, 50(2): 46-48.

Hutchison T.W. (1969). Economists and Economic Policy in Britain After 1870, History of Political Economy, 1(1): 231-255.

Jacoby N.H. (1971). The President, the Constitution, and the Economist in Economic Stabilization, History of Political Economy, 3(2): 398-414.

Keynes J.M. (1936). The General Theory of Employment, Interest and Money, London, Macmillan.

Kirchgässner G. (1999). On the Political Economy of Economic Policy Advice. In Mohr (ed.)(1999): 13-31.

Krueger A.O. (1999). The Use and Misuse of Theory in the Transfer Process. In Mohr (ed.)(1999): 32-44.

Machlup F. (1960). Economic Theory and Economic Policy - Discussion, The American Economic Review, 50(2): 48-52.

McCloskey D. (1986). Economics as an Historical Science. In Parker (ed.)(1986): 63-69.

Mohr E. (ed.)(1999). The Transfer of Economic Knowledge, Cheltenham: Edward Elgar.

Myrdal G. (1954). The Political Element in the Development of Economic Theory, London: Simon and Schuster, reprinted 1969 from the translation from German, Das Politische Element in der nationalöconomischen Doktrinbildung, Junker and Dünnhaupt Verlag, 1932.

Parker W.N. (ed.)(1986). Economic History and the Modern Economist, Oxford, Basil Blackwell.

Parsons W. (1989). The Power of Financial Press, Aldershot, Edward Elgar.

Pechman J. (ed.)(1989). The Role of the Economist in Government: An International Perspective, New York, Harvester Wheatsheaf

Rees A. (1986). The Marketplace of Economic Ideas, The American Economic Review, 76(2): 138-140.

Rostow W.W. (1957). The Interrelation of Theory and Economic History, The Journal of Economic History, 17(4): 509-523.

Rostow W.W. (1986). Professor Arrow on Economic Analysis and Economic History. In Parker (ed.)(1986): 70-76

Samuelson P.A. (1962). Economists and the History of Ideas, The American Economic Review, 50(1): 1-18.

Seldon A. (ed.)(1981). The Emerging Consensus...? Essays on the Interplay between 
Ideas, Interests and Circumstances in the First 25 Years of the IEA, London, The Institute of Economic Affairs.

Shackle G.L.S. (1966). The Nature of Economic Thought. Selected Papers 1955-1964, Cambridge, Cambridge University Press.

Smith J.A. (1989). Think Tanks and the Politics of Ideas. In Colander and Coats (eds.)(1989): 175-194.

Solow R.M. (1971). Science and Ideology in Economics, The Public Interest, 23(1): 94107; reprinted in Hausman (ed.)(1994): 239-251.

Solow R.M. (1986). Economics: Is Something Missing? In Parker (ed.)(1986): 21-29.

Spengler J.J. (1960). Economic Theory and Economic Policy - Discussion, The American Economic Review, 50(2): 52-54.

Stigler G.J. (1960). The Influence of Events and Policies on Economic Theory, The American Economic Review, 50(2): 36-45.

Stigler G.J. (1965). The Economist and the State, The American Economic Review, 55(1/2): $1-18$.

Temin P. (1986). Is History Stranger than Theory? The Origin of Telephone Separations. In Parker (ed.)(1986): 50-59.

Tomlinson J.D. (1984). A “Keynesian Revolution” in Economic Policy-Making?, The Economic History Review, 37(2): 258-262.

Wedel J. (2001). Collision and Collusion. The Strange Case of Western Aid to Eastern Europe, New York, Palgrave.

Winch D. (1969). Economics and Policy: A Historical Study, London, Hodder \& Stoughton.

Wright G. (1986). History and the Future of Economics. In Parker (ed.)(1986): 77-82.

Wyplosz C. (1999). The Culture of Economic Policy Advice: an International Comparison with Special Emphasis on Europe. In Mohr (ed.)(1999): 47-73.

\section{AbSTRACT}

Facts, theories, and policies can be considered as the vertices of a triangle. While many contributions explore along the edges of such triangle, between couples of poles, we claim that the history of economics thought is fundamentally interested in looking within the whole area of the triangle.

The relationship among theories, public choices, and events is complex, often twodirectional, with some unforeseeable short circuits. In order to tackle such complexity, it is necessary to use an interpretative model that assumes a high degree of interdependence between such variables and focuses on the evolution of their mutual interactions over time.

The paper aims to show that this is the approach that the works presented in this issue of the journal try to address and illustrates some of their key features, in particular country-specificity and ideological bias.

Jel Classification: A12, B10, B41

Keywords: History of economic thought, ideologies, country-specificity 